Bangladesh J. Bot. 43(3): 255-260, 2014 (December)

\title{
FREE RADICALS SCAVENGING -ANTIOXIDANT PHYTOCHEMICALS IN CHERRY TOMATO (SOLANUM LYCOPERSICON VAR. CERESIFORME (DUNAL) A. GRAY)
}

\author{
Gyanendra Kumar RaI*, RaJesh Kumar, RanjeEt Ranjan Kumar ${ }^{1}$ \\ AND SHEETAL DOGRA ${ }^{2}$
}

Indian Institute of Vegetable Research, Varanasi, (UP) India

Key words: Cherry tomato, Phytochemicals, Scavenging antioxidants, Lycopene and phenolics

\begin{abstract}
Significant differences $(\mathrm{p} \leq 0.05)$ were observed among the cherry tomato lines for the principal antioxidants, viz. total carotenoids, lycopene and vitamin-C. Vitamin-C content ranged from $17.62-46.16$ $\mathrm{mg} / 100 \mathrm{~g}$, the total carotenoid content ranged from $3.86-6.66 \mathrm{mg} / 100 \mathrm{~g}$ and lycopene content ranged from $2.83-5.26 \mathrm{mg} / 100 \mathrm{~g}$ on fresh weight basis. The total phenolics, another important class of antioxidants, also differed significantly amongst the cherry tomato line $(12.41-31.17 \mathrm{mg}$ gallic acid equivalent/100 g). Significant variation $(\mathrm{p} \leq 0.05)$ was also observed for $\mathrm{pH}$ and titrable acidity. The $\mathrm{pH}$ varied from $4.15-4.52$ and anhydrous citric acid ranged from 0.050 up to $0.323 \%$. The total soluble solids were $3.41-5.16 \%$. The maximum vitamin-C content was recorded in VRCT-6 $(46.16 \mathrm{mg} / 100 \mathrm{~g})$ closely followed by VRCT-7 (45.51 $\mathrm{mg} / 100 \mathrm{~g})$ and VRCT-15 $(44.71 \mathrm{mg} / 100 \mathrm{~g})$, whereas maximum total carotenoid content were recorded in VRCT-16 (6.66 mg/100 g) followed by VRCT-7 (6.48 mg/100 g) and VRCT-1(6.36 mg/100 g), respectively. On the other hand, maximum lycopene content was estimated in VRCT-16 (5.26 mg/100 g) followed by VRCT-3 (5.23 mg/100 g) and VRCT-14 $(4.73 \mathrm{mg} / 100 \mathrm{~g})$. Maximum acidity and total water soluble solids were recorded in VRCT-9 $(0.323 \%)$ and VRCT-7 $(5.16 \%)$, respectively.
\end{abstract}

\section{Introduction}

Tomato (Solanum lycopersicum L. Mill.), is the second most cultivated vegetable crop in the world, after potato, with an annual production of nearly 108 ton of fresh tomato in $3.7 \times 10^{6}$ hectare worldwide (FAO 2004). This vegetable is beneficial to human health, because of its potent of phytochemicals content such as lycopene, $\beta$-carotene, flavonoids, vitamin $\mathrm{C}$ and many essential nutrients (Beutner et al. 2001). This composition explains the high antioxidant capacity in both fresh and processed tomatoes (Gahler and Bohm 2003).

Interest in the role of free radical scavenging-antioxidants in human health has prompted research in the field of horticulture and food science to assess fruits and vegetable antioxidants. The influence of cultivars (Abushita et al. 2000), cultural practices and ripening stage at harvest (Buta and Spaulding 1997) and storage conditions (Dragan and Tomaz 2006) on antioxidant accumulation have been studied with tomato. However, there is a lack of information about cherry tomato regarding antioxidant phytonutrients.

Cherry tomatos (Solanum lycopersicon var. ceresiforme (Dunal) A. Gray) are small (1 - $3 \mathrm{~cm}$ diameter) to large tomato species and flavored, succulent due to which it is becoming popular as salad tomato. Therefore, the present investigation was carried out to evaluate the major phytochemicals in cherry tomato with special attention to compound playing significant roles in

*Author for correspondence: <gkrai75@gmail.com>, School of Biotechnology, Faculty of Agriculture, Shere-Kashmir University of Agricultural Sciences and Technology-Jammu, Chatha, Jammu 180009 (J\&K). ${ }^{1}$ Division of Biochemistry, Indian Agricultural Research Institute, New Delhi. ${ }^{2}$ Division of Vegetable Science and Floriculture, S.K. U.A.S.T.-Jammu. 
determining the antioxidant activity as well as nutritional value in cherry tomato. Therefore, the present investigation was carried out to evaluate the major phytochemicals in cherry tomato with special attention to compounds playing significant roles in determining the antioxidant activity as well as nutritional value in tomato.

\section{Materials and Methods}

Seventeen lines of cherry tomato were selected randomly from a replicated trail on tomato crop improvement at the Indian Institute of Vegetable Research Farm, during 2006-2007. Fruit samples were harvested randomly, when first fruits of the second truss reached the full ripening stage. Twenty five proximal fruits of each second truss were pooled from all the three replications, mixed thoroughly and analysed for various biochemical parameters. Soluble solids were analysed by a portable hand refractometer and the results are reported as Brix degrees at $20^{\circ} \mathrm{C}$. The $\mathrm{pH}$ of tomato juice was measured using a bench top $\mathrm{pH}$ meter (Orion-420A). Titratable acidity was estimated by the method of Rangana (1976). The acidity is expressed as per cent anhydrous citric acid. The ascorbic acid content was estimated titrimetrically, using 2, 6-dichlorophenol indophenols (2, 6-DCPIP) dye, as per the method of Rangana (1976). Ascorbic acid content was calculated as ascorbic acid $\mathrm{mg} / 100 \mathrm{~g}$ edible portion. The total carotenoid contents were estimated, as described by Thimmaiah (1999). Absorbance measured at $452 \mathrm{~nm}$ and total carotenoid content $(\mathrm{mg} / 100 \mathrm{~g})$ was calculated using a calibration curve prepared against a high purity $\beta$ carotene. Lycopene was analysed according to Thimmaiah (1999). The absorbance was measured at $503 \mathrm{~nm}$ in a UV-visible double beam Spectrophotometer (Shimadzu UV-1601). The lycopene content $(\mathrm{mg} / 100 \mathrm{~g})$ was calculated using molar extinction coefficient $\left(\sum=17.2 \times 10^{4}\right)$. The total phenolic content was analysed spectrophotometrically using the Folin-Ciocalteu colorimetric method at 650 $\mathrm{nm}$ (Singleton 1999). All values were expressed as mean (mg gallic acid equivalents/100 g fresh weight). The differences between the lines were tested using 1-way analysis of variance (ANOVA) and DMRT was used to determine the significant differences among the test materials. Differences were considered to be significant at $\mathrm{p} \leq 0.05$.

\section{Results and Discussion}

The titrimetric analysis of ascorbic acid showed significant variation in vitamin $\mathrm{C}$ levels amongst the cherry tomato lines [LSD $(\mathrm{p} \leq 0.05) 3.082$ ]. Vitamin $\mathrm{C}$ concentration ranged from 17.62 - $46.16 \mathrm{mg} / 100 \mathrm{~g}$ (Table 1). Maximum ascorbic acid content was recorded in 'VRCT-6 $46.16 \mathrm{mg} / 100 \mathrm{~g}$ ) and VRCT-7 $(45.51 \mathrm{mg} / 100 \mathrm{~g})$. Singh et al. (2004) reported ascorbic acid content in 15.70 to $28.50 \mathrm{mg} / 100 \mathrm{~g}$ in 15 cultivars of tomato. Similar findings, Sharma et al. (1996) reported ascorbic acid content ranged from $11.21-53.29 \mathrm{mg} / 100 \mathrm{~g}$ in 53 genotypes of tomato. The biological function of vitamin $\mathrm{C}$ is based on its ability to donate electrons, which provides intraand extra-cellular reducing power for a variety of biochemical reactions. In mammalian cells, vitamin $\mathrm{C}$ serves as a co-factor for reactions that require reduced iron and or copper metalloenzymes (Tsao 1997). Substantially high cellular levels of vitamin C provide antioxidant protection against photosynthetically generated free radicals (Delamere 1996). Another important indirect function of vitamin $\mathrm{C}$ is its ability to regenerate other biologically important antioxidants such as glutathione and vitamin $\mathrm{E}$ into their reduced state (Jacob 1995). The vitamin A activity of tomato fruit is determined mainly by the carotenoids content, thus the tomato cultivars were also evaluated for total carotenoids. Significant variation $(p \leq 0.05)$ was recorded in the carotene content amongst the 17 cherry tomato lines (Table 1). The values for carotenoid ranged from 3.86 up to $6.66 \mathrm{mg} / 100 \mathrm{~g}$ (Table 1). Maximum carotene content was recorded in VRCT-16 (6.66 $\mathrm{mg} / 100 \mathrm{~g})$ followed by VRCT-1 $(6.36 \mathrm{mg} / 100 \mathrm{~g})$. The total carotenoids content values recorded in 
this study confirm those reported by Singh et al. (2007) who reported that the total carotenoids values varied from $1.00-9.47 \mathrm{mg} / 100 \mathrm{~g}$ in 40 tomato genotypes. Raffo et al. (2002) reported that the carotenoid contents of tomato were very low at the breaker stage $(1.08 \mathrm{mg} / 100 \mathrm{~g})$, which increased $\geq$ ten-fold during ripening and reached $12.705 \mathrm{mg} / 100 \mathrm{~g}$ at full ripening stage. Significant variation in lycopene (the red pigment of tomato fruit) was also recorded [LSD $(\mathrm{p} \leq 0.05) 0.582]$ in this study and the values ranged from 2.83 up to $5.26 \mathrm{mg} / 100 \mathrm{~g}$. The values of lycopene are in close proximity to the published data on different varieties from India (Singh et al. 2007) and to those of Clinton (1998) who reported that the yellow cultivars contain about 0.5 $\mathrm{mg} / 100 \mathrm{~g}$ and the red ones as high as $9.0 \mathrm{mg} / 100 \mathrm{~g}$. Audrius et al. (2009) reported that the lycopene content in luthiana tomato varied from $8.55-13.56 \mathrm{mg} / 100 \mathrm{~g}$. Abushita et al. (1997) reported that the lycopene content in 12 tomato cultivars, which ranged from $5.180-8.470$ $\mathrm{mg} / 100 \mathrm{~g}$. Lycopene is the most abundant carotene in red tomato fruits, accounting for $90 \%$ of the total amount of carotenoids (Audrius et al. 2008). Typical red pigmented tomato fruits also contain lesser amount of $\beta$ carotene and other carotenoids.

Table 1. Antioxidant phytochemicals (Ascorbic acid, total carotenoids, lycopene and total phenolics ) content in cherry tomato.

\begin{tabular}{lcccc}
\hline $\begin{array}{l}\text { Cherry tomato } \\
\text { lines }\end{array}$ & $\begin{array}{c}\text { Ascorbic acid } \\
(\mathrm{mg} / 100 \mathrm{~g})\end{array}$ & $\begin{array}{c}\text { Total carotenoids } \\
(\mathrm{mg} / 100 \mathrm{~g}\end{array}$ & $\begin{array}{c}\text { Lycopene } \\
(\mathrm{mg} / 100 \mathrm{~g})\end{array}$ & $\begin{array}{c}\text { Total phenolics } \\
(\mathrm{mg} / 100 \mathrm{~g})\end{array}$ \\
\hline VRCT-1 & 24.01 & 6.36 & 4.20 & 23.45 \\
VRCT-2 & 17.62 & 5.33 & 3.50 & 31.17 \\
VRCT-3 & 28.46 & 6.26 & 5.23 & 20.54 \\
VRCT-4 & 44.21 & 4.76 & 3.03 & 29.78 \\
VRCT-5 & 36.49 & 5.84 & 4.50 & 15.68 \\
VRCT-6 & 46.16 & 5.76 & 3.88 & 30.69 \\
VRCT-7 & 45.51 & 6.48 & 4.58 & 27.39 \\
VRCT-8 & 35.66 & 5.73 & 3.26 & 31.08 \\
VRCT-9 & 40.36 & 5.93 & 4.54 & 25.03 \\
VRCT-10 & 39.44 & 5.78 & 3.76 & 12.41 \\
VRCT-11 & 35.69 & 3.86 & 2.83 & 29.62 \\
VRCT-12 & 36.53 & 5.13 & 3.13 & 31.17 \\
VRCT-13 & 42.62 & 5.86 & 3.70 & 21.70 \\
VRCT-14 & 27.75 & 5.78 & 4.73 & 25.13 \\
VRCT-15 & 44.71 & 4.73 & 3.23 & 28.87 \\
VRCT-16 & 36.39 & 6.66 & 5.26 & 16.98 \\
VRCT-17 & 35.53 & 6.06 & 4.10 & 25.61 \\
Mean & 36.30 & 5.66 & 3.96 & 25.07 \\
Range & $17.62-46.16$ & $3.86-6.66$ & $2.83-5.26$ & $12.41-31.17$ \\
LSD $(\mathrm{p}=0.05)$ & 3.082 & 0.698 & 0.582 & 3.224 \\
\hline
\end{tabular}

Phenolic compounds are secondary metabolites which are synthesized in plants. They possess biological properties such as antioxidant, anti-apoptosis, anti-aging, anticarcinogen, antiinflammation, anti-artherosclerosis, cardiovascular protection, improvement of the endothelial function, as well as inhibition of angiogenesis and cell proliferation activity. Most of these biological actions have been attributed to their intrinisic reducing capabilities (Han et al. 2007). The phenolic contents of tomato fruits at ripening stage were estimated in all 17 lines of cherry tomato. Significant variation in the phenolic contents were observed in the test cherry tomato lines 
[LSD $(\mathrm{p} \leq 0.05) 3.224]$. The mean values for phenolic content varied from $12.41-31.17 \mathrm{mg} / 100 \mathrm{~g}$ tomato fruit. Maximum phenol content was observed in VRCT-7 $(31.17 \mathrm{mg} / 100 \mathrm{~g})$. The least amount of phenols was estimated in VRCT-10 (12.41 mg/100 g). Martinez-Valverde et al. (2002) reported the phenol content (expressed chlorogenic acid) in range of 1.43-3.28 mg/100g for Spanish commercial varieties of tomato. They have also reported that the phenolic concentrations declined gradually during ripening. In their study maximum phenolic content was recorded at green yellow stage $(4.19 \mathrm{mg} / 100 \mathrm{~g})$, which subsequently decreased up to $0.91 \mathrm{mg} / 100 \mathrm{~g}$ at ripening stage.

The other quality parameters, viz. $\mathrm{pH}$, acidity and total water soluble solids (TSS), essential for flavour and processing needs, were also estimated. The $\mathrm{pH}$ of tomato fruit ranged from 4.15 4.52 amongst 17 cherry tomato lines. Total soluble solids (TSS) ranged between 3.41 and $5.16 \%$ (Table 2). The acidity ranged from $0.050-0.323 \%$ [LSD $(\mathrm{p} \leq 0.05)]$. Cherry tomato line VRCT-7 showed the maximum TSS (5.16\%) as well as maximum acidity $(0.323 \%)$ and lowest $\mathrm{pH}(4.15)$

Table 2. Variation in pH, acidity and total soluble solids (TSS) in cherry tomato.

\begin{tabular}{lccc}
\hline $\begin{array}{l}\text { Cherry tomato } \\
\text { lines }\end{array}$ & $\mathrm{pH}$ & $\begin{array}{c}\text { Acidity \% (anhydrous } \\
\text { citric acid) }\end{array}$ & $\begin{array}{c}\text { Total soluble solids } \\
(\%)\end{array}$ \\
\hline VRCT-1 & 4.15 & 0.096 & 3.61 \\
VRCT-2 & 4.23 & 0.100 & 4.57 \\
VRCT-3 & 4.37 & 0.056 & 4.23 \\
VRCT-4 & 4.24 & 0.110 & 4.09 \\
VRCT-5 & 4.26 & 0.064 & 4.20 \\
VRCT-6 & 4.35 & 0.056 & 4.27 \\
VRCT-7 & 4.40 & 0.060 & 5.16 \\
VRCT-8 & 4.52 & 0.050 & 4.23 \\
VRCT-9 & 4.15 & 0.323 & 3.99 \\
VRCT-10 & 4.36 & 0.130 & 3.98 \\
VRCT-11 & 4.32 & 0.093 & 3.41 \\
VRCT-12 & 4.32 & 0.064 & 4.18 \\
VRCT-13 & 4.22 & 0.140 & 4.13 \\
VRCT-14 & 4.29 & 0.156 & 4.64 \\
VRCT-15 & 4.23 & 0.110 & 4.70 \\
VRCT-16 & 4.16 & 0.160 & 3.58 \\
VRCT-17 & 4.50 & 0.072 & 4.56 \\
Mean & 4.29 & 0.108 & 4.20 \\
Range & $4.15-4.52$ & $0.050-0.323$ & $3.58-5.16$ \\
LSD $(\mathrm{p}=0.05)$ & 0.200 & 0.0055 & 0.423 \\
\hline & & & \\
\hline
\end{tabular}

were observed in VRCT-9 (Table 2). The TSS, $\mathrm{pH}$ and acidity values recorded in this study confirm those reported by Singh et al. (2007). They also reported that the TSS ranged from 3.06 $6.13 \%, \mathrm{pH}$ varied from $3.76-4.56$, and acidity (citric acid) range from $0.202-0.710 \%$ amongst 40 genotypes of tomato. Stevens et al. (1977) showed that fructose and citric acid were more important to sweetness and sourness, rather than glucose and malic acid and $\mathrm{pH}$ was a better objective measure of sourness than titratable acidity. It has shown that a high acid and a higher sugar concentration in tomato fruit generally improve the organoleptic quality and flavour in tomato. 
Thus cherry tomato is an excellent source of nutrients, specially vitamin C, total carotenoids as well as phenolics, which are the major contributors to the antioxidant activity of the fruit. The maximum ascorbic acid content was recorded in VRCT-6 followed by VRCT-7 and VRCT-15 whereas the maximum total carotenoid contents were recorded in VRCT-16, VRCT-7 and VRCT1. The maximum lycopene was recorded in VRCT-16 and VRCT-3 whereas VRCT-8, VRCT-2 and VRCT-12 had maximum phenol content. The information related to the significant variability these antioxidant phytochemicals in the cherry tomato observed in the present study can be utilized in the breeding programme to develop tomato/cherry tomato genotypes with higher antioxidant potential.

\section{References}

Abushita AA, Daood HG and Biacs PS 2000. Changes of carotenoid and antioxidant vitamins in tomato as a function of varietal and technological factors. J. Agri. and Food Chem. 48: 75-81.

Abushita AA, Hebshi EA, Daood HG and Biacs PS 1997. Determination of antioxidant vitamins in tomato. Food Chemistry 60: 207-212.

Audrius R, Pranas V and Ceslovas B 2008. Quality and physiological parameters of tomato (Lycopersicon esculentum Mill.) fruits of Lithuanian selection. Biologija. 54: 108-111.

Audrius R, Rasa K, Ceslovas B and Pranas V 2009. Nutrition quality of different tomato cultivars. Zemdirbyste-Agriculture 96: 67-75.

Beecher GR 1998. Nutrient content of tomatoes and tomato products. Proceding of Society of Experimental Biology and Medicine 218: 98-100.

Beutner S, Bloedorn B, Frixel S, Blanco IH, Hoffman T and Martin H 2001. Quantitative assessment of antioxidant properties of natural colorants and phytochemicals: carotenoids, flavonoids, phenols and indigoids. The role of $\beta$-carotene in antioxidant functions. J. Sci. Food and Agril. 81: 559-568.

Buta JG and Spaulding DW 1997. Endogenous level of phenolics in tomato fruits during growth and maturation. J. Plant Growth Regulation 16: 43-46.

Clinton S 1998. Lycopene: Chemistry biology and implication for human health and disease. Nutritional Review 56: 35-51.

Delamere NA 1996. Ascorbic acid and the eye subcell. Biochem. 25: 313-329.

Dragan Z and Tomaz P 2006. Comparative study of quality changes in tomato cv. 'Malike' (Lycopersicon esculentum Mill.) whilst stored at different temperatures. Acta Agric. Slovenica 87: 235-243.

Dumas Y, Dadomo M, Di Lucca G and Grolier P 2003. Effects of environmental factors and agricultural techniques on antioxidant content of tomatoes. J. Sci. Food and Agril. 83: 369-382.

FAO, Crop Description and Climate. 2004. Available: http://www.fao.org/ag/agl/aglw/cropwater/tomato.stm \#-descrip [24 January 2005].

Gahler S, Otto K and Bohm V 2003. Alterations of vitamin C, total phenolics and antioxidant capacity as affected by processing tomatoes to different products. J. Agril. and Food Chem. 51: 7962-7968.

George B, Kaur C, Khurdiya DS and Kapoor HC 2004. Antioxidants in tomato (Lycopersicon esculentum) as a function of genotype. Food Chem. 84: 45-51.

Han X, Shen T and Lou H 2007. Dietary Polyphenols and Their Biological Significance. Intl. J. Mol. Sci. 8: 950-988.

Jacob RA 1995. The integral antioxidant system. Nutrit. Res. 15: 755-766.

Martinez-Valverde I, Periago MJ, Proven G and chesson A 2002. Phenolic compounds, lycopene and antioxidant activity in commercial varieties of tomato (Lycopersicon esculentum). J. Food Sci. Agril.. 82: 323-330.

Raffo A, Leonari C, Fogliano V, Ambrosino P, Salucci M, Gennaro L, Bugianesi R, Giuffrida F and Qualgia G 2002. Nutritional value of Cherry tomatoes (Lycopersicon esculantum cv Naomi F1) Harvested at different ripening stages. J. Agril. Food Chem. 50: 6550-60. 
Ranganna S 1976. Hand book of analysis and quality control for fruits and vegetable products. (Edn.) 2, pp. 545. Tata Mc Graw Hill publishing Co. Ltd., New Delhi.

Rao AV, Waseen Z and Agarwal S 1998. Lycopene content of tomatoes and tomato products and their contribution to dietary lycopene. Food Res. Internat. 31: 737-741.

Rao AV and Agarwal S 2000. Role of antioxidant lycopene in cancer and heart disease. J. Amer. College of Nutrit. 19: 563-569.

Sharma S, Mahajan R and Bajaj KL 1996. Biochemical evaluation of some tomato varieties. Vegetable Sci. 23: $42-7$.

Singh J, Rai M, Kumar R, Verma A and Rai GK 2007. Genotyping variation and hierarchical clustering of tomato (Lycopersicon esculentum Mill.) based on morphological and biochemical traits. Vegetable Sci. 34: 40-45.

Singh J, Rai GK, Upadhyay AK, Kumar R and Singh KP 2004. Antioxident phytochemicals in tomato (Lycopersicon esculentum Mill.). Ind. J. Agril. Sci. 74: 3-5.

Singleton VL, Orthofer R and Lamuela Raventos RS 1999. Analysis of total phenols and other oxidation substrates and antioxidants by means of folin-ciocalteu reagent. Methods in Enzymology 299: 152-178.

Stevens MA, Kader AA, Albright-Holton M and Algazi M 1977. Genotype variation for flavour and composition in fresh market tomato. J. Amer. Soc. Hort. Sci. 102: 680-689.

Thimmaiah SK 1999. Standard method of biochemical analysis, Kalyani Publisher, New Delhi.

Toor RK and Savage GP. 2005. Antioxidant activity in different fractions of tomatoes. Food Res. Internat. 38: 487-494.

Tsao CS 1997. An overview of ascorbic acid chemistry and biochemistry. In: Packer, L. and Fuch, J. (eds).Vitamin C in health and diseases. Marcal Dekker, New York.

(Manuscript received on 18 November, 2012; revised on 2 July, 2014) 